\title{
Enzymatic Hydrolysis Performance of Biomass by the Addition of a Lignin Based Biosurfactant ${ }^{1}$
}

\author{
Widya FATRIASARI ${ }^{2}$ Fajar NURHAMZAH ${ }^{3} \cdot$ Rika RANIYA $^{4} \cdot$ R.Permana Budi LAKSANA ${ }^{2} \cdot$

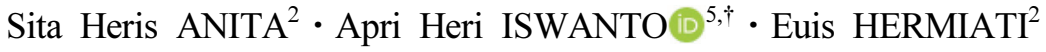

\begin{abstract}
Hydrolysis of biomass for the production of fermentable sugar can be improved by the addition of surfactants. In pulp and paper mills, lignin, which is a by-product of the pulping process, can be utilized as a fine chemical. In the hydrolysis process, lignin is one of the major inhibitors of the enzymatic breakdown cellulose into sugar monomer. Therefore, the conversion of lignin into a biosurfactant offers the opportunity to solve the waste problem and improve hydrolysis efficiency. In this study, lignin derivatives, a biosurfactant, was applied to enzymatic hydrolysis of various lignocellulosic biomass. This Biosurfactant can be prepared by reacting lignin with a hydrophilic polymer such as polyethylene glycol diglycidylethers (PEDGE). In this study, the effect of biosurfactants on the enzymatic hydrolysis of pretreated sweet sorghum bagasse (SSB), oil palm empty fruit bunch, and sugarcane trash with different lignin contents was investigated. The results show that lignin derivatives improve the enzymatic hydrolysis of the pretreated biomass with low lignin content, however, it has less influence on the enzymatic hydrolysis of other pretreated biomass with lignin content higher than $10 \%(\mathrm{w} / \mathrm{w})$. The use of biosurfactant on SSB kraft pulp can increase the sugar yield from $45.57 \%$ to $81.49 \%$.
\end{abstract}

Keywords: lignin content, lignocellulosic biomass, sugar yield, biosurfactant

\section{INTRODUCTION}

Lignin and crystalline structure of cellulose are known as major inhibitor in conversion of biomass into sugar and bioethanol production. Lignin acts as the glue that binds cellulose and hemicellulose via covalent and noncovalent bond, giving rigidity and re- sistance to lignocellulose (Wang et al., 2020). As a second major component of lignocellulose, lignin tends to have a significant negative influence on enzymatic hydrolysis resulting in low sugar yield. The high lignin content adversely affects the interaction between cellulase and cellulose. Besides that, the presence of lignin can also affect the path for cellulase

\footnotetext{
${ }^{1}$ Date Received July 7, 2020, Date Accepted August 10, 2020

${ }^{2}$ Research Center for Biomaterials LIPI, Jl Raya Bogor KM 46 Cibinong Bogor Indonesia 16911

${ }^{3}$ Diploma Program for Chemical Analysis, Bogor Agricultural University, Bogor 16151, Indonesia

${ }^{4}$ Department of Environmental Health, Faculty of Public Health, University of Indonesia, Depok Indonesia

${ }^{5}$ Department of Forest Product, Faculty of Forestry, Universitas Sumatera Utara, Padang Bulan, Medan 20155, Indonesia

† Corresponding author: Apri Heri ISWANTO (e-mail: apri@usu.ac.id, apriheri@yahoo.com, ORCID: 0000-0002-4243-1429)
} 
Widya FATRIASARI - Fajar NURHAMZAH - Rika RANIYA $\cdot$ R.Permana Budi LAKSANA •

Sita Heris ANITA - Apri Heri ISWANTO - Euis HERMIATI

action thus the hydrolysis becomes slow down (Qing et al., 2010). It was commonly found that lignin appeared to adsorb enzyme more easily than cellulose, leading to the reduce the effectiveness of enzyme activity (Rahikainen et al., 2013). To provide cellulose more accessible by cellulase and increase the possibility of interaction between cellulase and cellulose, the lignin in biomass should be removed by pretreatment. In the acid hydrolysis, lignin was reported inhibit cellulose and hemicellulose hydrolysis into glucose and xylose. Also, the hydrolysis of xylan to xylose and dehydration xylose to furfural from corncob was also interfered by the presence of lignin (Daorattanachai et al., 2013). Lower sugar yield was reported because of the presence of lignin that imply to require high enzyme dosage (Berlin et al., 2006).

In the field, Sugarcane thrash (ST) consists of leaves and tops of sugarcane plant usually left in the field as waste of sugarcane harvesting (Hermiati et al., 2020). ST is also just burnt at harvest (Hermiati et al., 2020) that can generate environmental problem in sugarcane plantation. It counts approximately 15-30\% of the total above ground biomass at harvest. In some reports, ST leaves contain 35\% cellulose, 23-30.8\% hemicellulose, and 10-22.9\% lignin (Moodley and Kana 2015, Jutakanoke et al., 2017, Gomez et al., 2014, Arnieyanto, 2018). Similar with ST, sweet sorghum bagasse (SSB) presents as by product of juice extraction of sweet sorghum stalk. This biomass is abundant but the further utilization into valuable materials is still limited (Fatriasari et al., 2015). Regarding its abundance and its chemical component (43.66\% cellulose, $35.63 \%$ hemicellulose, $24.59 \%$ acid insoluble lignin and $0.66 \%$ acid soluble lignin) (Solihat et al., 2017), SSB has been utilized as pulp and paper (Fatriasari et al., 2015; Patil et al., 2011; Kumar and Marimuthu, 2012), particle board (Iswanto et al., 2017), sugar and bioethanol (Solihat et al., 2017; Choudhary et al., 2012; Goshadrou et al., 2011; Wang et al., 2012).
Together with Malasyia, Indonesia includes in two biggest palm oil producers in the world (Wright and Wiyono, 2013). Oil palm empty fruit bunch (OPEFB) produces as by product of processing oil palm about 5.29 million tons of dry OPEFB in 2016 (Anita et al., 2020). It has $43.0 \% \alpha$-cellulose, $12.7 \%$ hemicellulose, $17.8 \%$ AIL, and $1.30 \%$ acid soluble lignin (Fatriasari et al., 2018).

Pre-treatment uses various techniques, including chemical treatment with acid solution (Hendriks et al., 2009; Singh et al., 2013; Fatriasari et al., 2017), alkaline solution (Xu et al., 2010; Sills and Gossett 2011, Fajriutami et al., 2016), ionic liquid (Elgharbawy et al., 2016; Han et al., 2020), are aimed to alter the structure of cellulosic biomass to make cellulose more accessible. Acid pre-treatment removes hemicellulose and facilitates the cellulase to break down cellulose into sugar monomer. Compared to inorganic acid such as sulfuric acid, utilization of organic acid such as maleic acid and oxalic acid can minimize generation of secondary degradation products including sugar degradation products and also phenolic compound which are toxic to microorganisms (Oktaviani et al., 2019; Anita et al., 2020). It presents a higher catalytic efficiency for hydrolysis under the same severity conditions (Anita et al., 2020). Meanwhile, alkali pretreatment aims to remove lignin from biomass matrix thus the cellulose is more easily to be accessed. Kraft pulping includes in alkali pre-treatment that reported could effectively degrade lignin in biomass with minimum carbohydrate degradation (Fatriasari et al., 2015). Its ability to handle various raw materials and its high chemical recovery efficiency ( $\sim 97 \%$ ) cause this process is favored over other pulping methods (Fortunati et al., 2016).

Besides that, in the bioconversion of biomass, the hydrolytic performance of cellulase enzymes can be enhanced by adding promoters such as surfactant (Jonsson et al., 2013). By combining the treatment i.e. 
removal of the barrier factor for hydrolysis and addition of surfactant, the performance of hydrolysis will improve. Surfactants, amphiphilic compounds, can reduce surface and interfacial tensions by accumulating at the interface of immiscible fluids, increasing the solubility, motility, bioavailability and subsequent biodegradation of hydrophobic or insoluble organic compounds (Abdeli et al., 2019). It could change the nature of the substrate, e.g., by increasing the available cellulose surface or by removing inhibitory lignin (Helle et al., 1993). In many studies, addition of some commercial surfactant such as PEG 6000, Tween 80 and glyceryl alcohol has increased hydrolytic performance (Zong et al., 2015). The adsorbed surfactant to lignin surface could prevent non-specific binding between enzyme and lignin, leading to enzyme deactivation. As a result, the hydrolysis rate would be enhanced (Kim et al., 1982; Kaar and Holtzapple, 1998; Yoon and Robyt, 2005; Eriksson et al., 2002). In addition, surfactant causes alteration of substrate structure and it can increase the ability to be accessed by enzymes (Kaar and Holtzapple, 1998). Surfactant also causes enzyme stabilization and prevent enzyme denaturation during hydrolysis (Kaar and Holtzapple, 1998; Kim et al., 1982). Other studies reported positive interaction between substrate and enzymes (Eriksson et al., 2002; Kaar and Holtzapple 1998; Malmsten and Van Alstine, 1996) after a surfactant addition on hydrolysis process.

Lignin, a by-product of pre-treatment process, has great potential to be converted into value-added products that could significantly enhance the economics of various industrial applications. Some researchers reported the use of lignin as an additive in pellet (Min and Um, 2017), as activated carbon (Mussattoa et al., 2010), as adhesives (Alinejad et al., 2019), and as water-soluble biosurfactant i.e. Amphiphilic Lignin Derivatives (A-LD). A-LD prevents non-productive absorption of enzyme in hydrolysis process (Winarni et al., 2013; Winarni et al., 2014; Uraki et al., 2001). The addition of A-LD in enzymatic hydrolysis process improved the digestibility of biomass (Cheng et al., 2017; Fatriasari et al., 2018) and the enzyme can be reused (Winarni et al., 2013). A-LD increases the stability of the enzymes during hydrolysis therefore improves the bioethanol production (Cheng et al., 2017).

As reported before, lignin isolated from Acacia mangium black liquor has been converted into biosurfactant. In our previous study, we evaluate the effect of lignin isolation method in A-LD preparation on enzymatic hydrolysis performance of kraft pulp of sweet sorghum bagasse (SSB) (Fatriasari et al., 2018). Based on previous study, the addition $5 \%$ of A-LD on enzymatic hydrolysis resulted in higher reducing sugar yield. After that, optimization of the synthesis condition in A-LD reaction has been conducted (Fatriasari et al., 2020) of the synthesis condition in A-LD reaction has been conducted. The optimized A-LD was used in this study. The effect of A-LD derived from $A$ mangium on enzymatic hydrolysis has not observed for other biomass with varies of lignin content. To ensure the improvement effect of A-LD addition, some pretreated biomass were used as substrate of the enzymatic hydrolysis.

\section{MATERIALS and METHODS}

\subsection{Materials}

Sweet sorghum bagasse (SSB) of Numbu variety was collected from BIOTROP plantation (Bogor, West Java, Indonesia) as by product of sugar juice extraction process of sorghum straw. Oil palm empty fruit bunch (OPEFB) was obtained from oil palm plantation in Cikasungka, West Java, Indonesia and sugarcane trash (ST) was from PT PG Rajawali II, Subang, West Java, Indonesia. ST consisted of sugarcane leaves and upper part of sugarcane plant which were left on the field after harvesting. A mangium kraft black liquor 
Widya FATRIASARI - Fajar NURHAMZAH - Rika RANIYA $\cdot$ R.Permana Budi LAKSANA •

Sita Heris ANITA - Apri Heri ISWANTO - Euis HERMIATI

with solid content of 70\% from PT Tanjung Enim Lestari Pulp and Paper (TELPP), South Sumatera, Indonesia was used for A-LD preparation. Polyethylene glycol diglycidylethers (PEDGE) Mn 500 in analytical grade was used in synthesis of A-LD. The commercial cellulase enzyme (Sigma-Aldrich) from Trichoderma reesei ATCC 26921 containing $42.3 \mathrm{FPU} / \mathrm{mL}$ was used for hydrolysis process. The other reagents for sugar analysis were of analytical grade.

\subsection{Methods}

\subsubsection{Pre-treatment}

\subsubsection{SSB kraft pulping}

SSB chips (250 g Oven Dried Weight/ODW) was delignified by kraft pulping using rotary digester. The pre-treatment was conducted with $17 \%$ active alkali and $20 \%$ sulfidity, liquid to solid ratio of 10 , temperature of $170{ }^{\circ} \mathrm{C}$ for $4 \mathrm{~h}$ following the Fatriasari et al. (2015). The moisture content, weight loss, and yield of pre-treated SSB were $79.15 \%, 43.39 \%$, and $56.61 \%$, respectively, while the reducing sugar yield without A-LD addition was $45.57 \%$ (Solihat et al., 2017).

\subsubsection{Microwave-assisted oxalic acid pre-treatment of OPEFB}

OPEFB was pre-treated with oxalic acid at the optimum condition according to Anita et al. (2020). Three grams ODW of OPEFB (40-60 mesh) and $30 \mathrm{~mL}$ of oxalic acid solution $(1.13 \% \mathrm{v} / \mathrm{v})$ were inserted in a Teflon tube. Afterward, the sample was heated by microwave digester (START D Microwave Digestion System, Milestone, Italy) at $190{ }^{\circ} \mathrm{C}$ for $3.01 \mathrm{~min}$, not including approximately $12 \mathrm{~min}$ pre-heating time to targeted temperature. After completed heating, the pre-treated samples were filtered to separate solid and liquid fraction. The moisture content, weight loss, and pulp recovery of OPEFB pre-treated by oxalic acid were $68.27 \%, 41.07 \%$ and $58.93 \%$, respectively. The reducing $\mathrm{s}$ of OPEFB pre-treated oxalic acid without A-LD addition was $34.20 \%$ (Anita et al., 2020).

\subsubsection{Microwave-assisted maleic acid pretreat- ment of OPEFB}

OPEFB was also pre-treated with microwave assisted MA using the optimum condition as reported in Fatriasari et al. (2016). As much as $3 \mathrm{~g}$ ODW OPEFB (40-60 mesh) was inserted into Teflon tube and then $30 \mathrm{~mL}$ of MA solution $1.2 \%(\mathrm{w} / \mathrm{v})$ was added. The pre-treatment was conducted at $185{ }^{\circ} \mathrm{C}$ for $2.8 \mathrm{~min}$. The liquid fraction was separated from solid fraction by filtration. The solid fraction was used in enzymatic hydrolysis with A-LD addition. The weight loss and pulp recovery of OPEFB after pre-treatment were $36.3 \%$ and $63.34 \%$, respectively with $67.32 \%$ of moisture content. The reducing sugar yield of OPEFB pre-treated by MA in this optimum condition was $52.42 \%$ (Fatriasari et al., 2016)

\subsubsection{Microwave-assisted maleic acid pre-treat- ment of ST}

The pre-treatment of ST was conducted by following the method of Arnieyanto (2018). Three grams ODW of sugarcane trash (ST) (40-60 mesh) was inserted into Teflon tube and then added with $30 \mathrm{~mL}$ of maleic acid solution ( $\mathrm{pH} 2$ ). The microwave pretreatment was conducted at $180{ }^{\circ} \mathrm{C}$ for $5 \mathrm{~min}$, not including approximately $12 \mathrm{~min}$ pre-heating time to targeted temperature and $10 \mathrm{~min}$ cooling time. After irradiation the tubes were cooled in an ice bath for 30 min. The solid fraction was obtained by filtering the through filter paper by vacuum filtration. The solid fraction was to be subjected in enzymatic hydrolysis with A-LD addition.

\subsubsection{A-LD preparation}

Lignin isolation from $A$. mangium black liquor was conducted according to method of Fatriasari et al. 
(2018). There are two kinds of crude A-LD including A-LD $\mathrm{L}_{1} \mathrm{~S}$ and A-LD $\mathrm{L}_{2} \mathrm{~S}$ which were synthesized from kraft lignin 1 step $\left(\mathrm{L}_{1} \mathrm{~S}\right)$ and 2 step $\left(\mathrm{L}_{2} \mathrm{~S}\right)$ isolation method. The A-LD was prepared following the optimum condition of synthesis that reported by Fatriasari et al. (2020). One gram of $\mathrm{L}_{1} \mathrm{~S}$ and $3 \mathrm{~g}$ of PEDGE were used for A-LD $\mathrm{L}_{1} \mathrm{~S}$ synthesis, while the amount of $\mathrm{L}_{2} \mathrm{~S}$ and PEDGE for A-LD $\mathrm{L}_{2} \mathrm{~S}$ synthesis were $0.6 \mathrm{~g}$ and $2 \mathrm{~g}$, respectively. Both variations were reacted at $60{ }^{\circ} \mathrm{C}$ for $1 \mathrm{~h}$. A-LD LS (commercial lignin) was synthesized by reacting $0.6 \mathrm{~g}$ of LS and 3 $\mathrm{g}$ of PEDGE at $60{ }^{\circ} \mathrm{C}$ for $2 \mathrm{~h}$. Three variations of A-LD were added in enzymatic hydrolysis of pretreated biomass.

\subsubsection{Enzymatic hydrolysis and sugar analysis}

A $200 \mathrm{mg}$ ODW of pretreated biomass was inserted into $100 \mathrm{~mL}$ of conical flask and then added with $200 \mu \mathrm{L} 2 \% \mathrm{w} / \mathrm{v}$ sodium azide, $10 \mathrm{~mL}$ sodium citrate buffer $(0.05 \mathrm{M}, \mathrm{pH} 4.8), 30 \mathrm{FPU} / \mathrm{g}$ substrate of cellulase enzyme, and 5\% A-LD/ODW substrate with total volume of $20 \mathrm{~g}$ obtained. Subsequently, the mixed samples were incubated using incubator shaker (WiseCube WIS-30R) at a rate of $150 \mathrm{rpm}$, and 50 ${ }^{\circ} \mathrm{C}$ for $72 \mathrm{~h}$. The control of substrate, enzyme, and buffer was also prepared besides the samples. The replication of enzymatic hydrolysis was conducted in triplicate. After process completed, the mixtures were centrifuged at $10.000 \mathrm{rpm}$ for $5 \mathrm{~min}$ to separate the supernatant from the residue, which was specifically placed in a freezer at temperatures of $5-10{ }^{\circ} \mathrm{C}$. The supernatant was determined for its reducing sugar concentration using DNS method Miller (1959) by UV-Vis Hitachi U-2001 at wavenumber of $540 \mathrm{~nm}$. By considering the weight loss during pre-treatment and reducing sugar concentration of the hydrolysate, the reducing sugar yield per biomass $(\mathrm{g} / 100 \mathrm{~g})$ were calculated based on the equation of Anita et al. (2020) with adjustment in total weight of enzymatic hydrolysis solution is $20 \mathrm{~g}$ that equal to $20 \mathrm{~mL}$.

\subsubsection{Chemical content analysis of pre-treated biomass}

The chemical content of pre-treated biomass (ST and OPEFB) was analysed, including EtOH-benzene content (TAPPI T204 cm-97 1997), ash content (TAPPI T211 om-02, 2002), acid soluble lignin and Acid insoluble lignin (AIL) (Sluiter et al., 2012), holocellulose content (Wise et al., 1946), $\alpha$-cellulose content (Rowell et al., 2005). The hemicellulose content was obtained by subtracting the holocellulose content with $\alpha$-cellulose content (Punyamurthy et al., 2013).

\subsubsection{Combined Severity factor of organic acid pre-treatment}

To estimate organic acid pre-treatment severity and comparing with pre-treatment method, the severity factor (SF) and combined severity factor (CSF) that estimate the effect of an acidic catalyst (Jang et al., 2016) were determined using Eq.1 and 2, respectively (Goh et al., 2012, Marklein et al., 2016). The SF does not take into account any acids used as a catalyst in the process (Marklein et al., 2016).

$$
\mathrm{SF}=\log (\mathrm{R} 0)=\log \left(\mathrm{t}^{*} \exp \left(\mathrm{T}-\mathrm{T}_{100}\right)\right) / 14.7
$$

where $\mathrm{t}$ is the irradiation time ( $\mathrm{min}$ ), and $\mathrm{T}$ is the reaction temperature $\left({ }^{\circ} \mathrm{C}\right)$.

The CSF (Eq.2) was determined based on the equation of Lee et al. (2010) and Loow et al. (2016) with considering the $\mathrm{pH}$ of the solution

$$
\mathrm{CSF}=\log (\mathrm{R} 0)-\mathrm{pH}
$$


Widya FATRIASARI - Fajar NURHAMZAH - Rika RANIYA $\cdot$ R.Permana Budi LAKSANA •

Sita Heris ANITA - Apri Heri ISWANTO - Euis HERMIATI

\subsubsection{X-ray diffraction analysis of pre-treated biomass}

Crystallinity index of OPEFB pre-treated maleic acid and oxalic acid, ST pre-treated maleic acid was determined using Shimadzu XRD-700 MaximaX while SSB kraft pulp and was analysed using Rigaku SmartLab. The operation condition was $2 \theta$ of $10-40^{\circ}$ with $\mathrm{Cu}-\mathrm{K} \alpha$ radiation operated at $30 \mathrm{~mA}$ and $40 \mathrm{kV}$, and the crystallinity index $(\mathrm{CI})$ was calculated based on Eq.3 (Focher et al., 2001).

$$
\mathrm{CI}(\%)=\frac{\mathrm{Fc}}{\mathrm{Fa}+\mathrm{Fc}} \times 100
$$

$\mathrm{Fc}$ and $\mathrm{Fa}$ denote the area of the crystalline region and non-crystalline region, respectively.

\section{RESULTS AND DISCUSSION}

\subsection{The effect of pre-treatment method on chemical composition of biomass}

In attempt to propose effective utilization as bioenergy of waste biomass i.e. ST, OPEFB and SSB, this study was conducted by evaluating the performance of pre-treated substrate for enzymatic hydrolysis with variation of their lignin content by addition of lignin based biosurfactant. Table 1 presents the comparison of chemical component of OPEFB, ST and SSB kraft pulp. Kraft pulping indicates as the most effective pre-treatment in removing lignin content in biomass. Kraft delignification facilitates in improving enzymatic hydrolysis performance (Monrroy et al., 2012). Solihat et al. (2017) reported that this pre-treatment has successfully removed $90 \%$ AIL and 50\% hemicellulose, respectively. This effective delignification is affected by the chemical used in kraft delignification i.e. sodium hydroxide $(\mathrm{NaOH})$ and sodium sulfide (Na2S). Alkali facilitates in removing lignin while hydrosulfide (HS-) and sulfide ions contained in $\mathrm{Na}_{2} \mathrm{~S}$ can preserve the cellulose by stabilization at the end group of cellulose chain. The ions have capability in accelerating delignification process by attacking $\beta$ ar$\mathrm{yl}$ ether bonds in lignin polymer resulting high pulp yield (Fengel and Wegener, 1989; Sjostrom, 1981). In other hand, organic acids such as maleic acid and oxalic acid can be combined with microwave pre-treatment to optimize the pre-treatment process. They belong to dicarboxylic acid that can disrupt the lignocellulosic structure and hydrolyze hemicellulose into xylose selectively. Oxalic acid or Maleic acid is suitable for pre-treatment in releasing fermentable hemicellulose sugars without degradation product for-

Table 1. Chemical composition of pre-treated biomass

\begin{tabular}{lcccc}
\hline \multicolumn{1}{c}{ Chemical component } & $\begin{array}{c}\text { OPEFB pre-treated by } \\
\text { maleic acid }\end{array}$ & $\begin{array}{c}\text { OPEFB pre-treated by } \\
\text { oxalic acid }\end{array}$ & $\begin{array}{c}\text { ST pre-treated by } \\
\text { maleic acid }\end{array}$ & $\begin{array}{c}\text { SSB pre-treated by } \\
\text { kraft } \\
\text { pulping }\end{array}$ \\
\hline \hline EtOH-benzene extractives (\%) & 7.56 & 7.49 & 2.24 & $\begin{array}{c}\text { Not reported } \\
\text { Ash content (\%) }\end{array}$ \\
Holocellulose & 0.57 & 0.83 & 4.34 & Not reported \\
$\quad$-cellulose (\%) & 70.27 & 71.68 & 69.90 & 93.83 \\
Hemicellulose (\%) & 60.92 & 61.12 & 39.32 & 64.65 \\
Lignin & 9.35 & 10.56 & 30.58 & 29.18 \\
Acid insoluble lignin (\%) & 23.44 & 10.92 & 23.77 & 1.49 \\
Acid soluble lignin (\%) & 19.56 & 10.03 & 19.88 & 0.81 \\
\hline
\end{tabular}

* Solihat et al. (2017), ** Anita et al. (2020) 
mation extensively. Both acids have greater effect in removing hemicellulose than that of lignin. Comparing with inorganic acid such as sulfuric acid (SA), the hydrolysis of $\beta-1-4$ glycosidic bonds by maleic acid is more selective (Fatriasari et al., 2018). Thus, it can be understood that the lignin content in biomass after kraft delignification was lower than those after the other pre-treatment methods. Comparing with mangkuang (Pandanus artocarpus Griff) that has been pretreated using biological-liquid hot water or liquid hot water-biological pre-treatment (Yanti et al., 2019), the kraft pulp of SSB and pulp of maleic acid/oxalic acid pre-treated OPEFB have higher cellulose and lower lignin content than does the mangkuang pulp. However, cellulose of kraft pulp of SSB is lower than that of soda pulp of jabon wood (79.85\%) with AIL of $4.56 \%$. Table 2 shows the SF of acid pre-treatment of biomass. The three acid pre-treatments tend to have similar SF and CSF with the highest SF and CSF are found in pre-treatment of OPEFB by maleic acid. Even though the CSF of oxalic acid pre-treatment OPEFB and maleic acid pre-treatment of ST are similar, the effect on chemical composition in the pre-treated maleic acid is different significantly, indicated by the much higher cellulose and lower hemicellulose content in the oxalic acid pre-treated OPEFB than those in the maleic acid pre-treated ST.

As known well that the presence lignin during hydrolysis can interfere the enzyme work to break down cellulose into its sugar monomer. Lignin was reported could absorp enzyme more easily than cellulose, thus, the enzyme cannot work effectively (Lee et al., 2010). During pre-treatment, a part of lignin can be solu- bilized. Besides that, lignin can undergo condensation and be deposited on the cellulose surface during pretreatment. It might block access enzyme into cellulose (Lai et al., 2014; Pareek et al., 2013). Lignin has significant negative effect on lowering sugar yield. Therefore, high enzyme dosage is required to achieve high sugar yield (Berlin et al., 2006). A surfactant addition in enzymatic hydrolysis is also the other method in improving high sugar achieved as reported in several previous studies after pre-treatment stage. Wang et al. (2020) reported alkali treated materials containing higher relative xylan contents with lower relative lignin contents has higher enzymatic efficiencies than acid treated materials. It means that xylan removal is less important than lignin removal. Based on CSF, the effectiveness of lignin removal by pre-treatment has different trend. Oxalic acid pre-treatment with the lowest CSF is more beneficial to OPEFB than does maleic acid pre-treatment in the removal of lignin and hemicellulose.

The ethanol-benzene extractives content of oxalic acid and maleic acid OPEFB are higher than that of $\mathrm{ST}$, while the ash content is vice versa. As non-structural component, extractives have also dissolved to facilitate enzyme accessibility into substrate (Fatriasari et al., 2018). Terpenoid compound, phenolic, waxes, fats, resins, oils, and tannins as well as certain components that are not soluble in ether can dissolve in alcohol-benzene solution (Lukmandaru, 2016; Sjostrom, 1998). Extractives of OPEFB that can dissolve in ethanol-benzene solution are greater than those of ST. This might be due to the oils and fats remained in the OPEFB after the palm oil was extracted from the fresh

Table 2. The severity factor of organic acid pre-treatment

\begin{tabular}{ccc}
\hline Pre-treatment method & Severity Factor (SF) & Combined Severity Factor (CSF) \\
\hline \hline OPEFB pre-treated maleic acid & 3.13 & 1.39 \\
OPEFB pre-treated oxalic acid & 2.95 & 1.03 \\
ST pre-treated maleic acid & 3.05 & 1.05 \\
\hline
\end{tabular}


Widya FATRIASARI - Fajar NURHAMZAH - Rika RANIYA $\cdot$ R.Permana Budi LAKSANA •

Sita Heris ANITA - Apri Heri ISWANTO - Euis HERMIATI

fruit bunch. A higher ash content can influence the enzymatic hydrolysis. The cations in ash contained in straw could migrate into the solution and affect the cellulase activities. In addition, the ash cation removal during pre-treatment can increase enzymatic hydrolysis efficiency especially at low concentration of cellulase (Bin et al., 2010). Therefore, high ash content in pre-treated ST might give more negative effect on enzymatic hydrolysis compared to pre-treated OPEFB.

Holocellulose is main component of biomass as source of sugar that consists of cellulose and hemicellulose. Maleic acid and oxalic acid assisted microwave pretreatment and kraft pulping are performed to facilitate enzyme to access carbohydrate more effectively. Based on Table 1, kraft pulping results in the highest $\alpha$-cellulose with comparable hemicellulose content with OPEFB pre-treated oxalic acid and maleic acid. It means that this pre-treatment facilitates delignification process and prevent extensive degradation of carbohydrate more effectively. Higher holocellulose content, means higher potency of sugar that can be converted into its sugar monomer. Even though the $\alpha$ cellulose content of SSB kraft pulp is comparable with acid pre-treated OPEFB, the hemicellulose contained in the SSB kraft pulp is very high. The high hemicellulose percentage in the SSB kraft pulp was caused by the high loss of lignin during the pulping process. Compared to $\alpha$-cellulose that has high molecular weight with straight bond structure, hemicellulose has lower molecular weight with branch structure polymer. This structure make hemicellulose can be hydrolysed more easily.

\subsection{The effect of lignin content in pre-treated biomass on enzymatic hydrolysis performance}

The proposed reaction between kraft lignin and PEDGE to result A-LD is shown in Fig. 1. Fig. 2, 4 and 5 show the effect of biosurfactant addition on enzymatic hydrolysis of pre-treated biomass with variation of lignin content on sugar concentration, reducing sugar yield per pulp and reducing sugar yield per

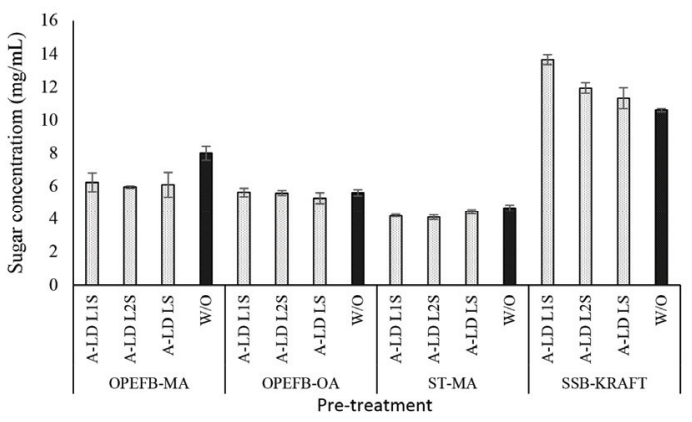

Fig. 2. Sugar concentration of pre-treated biomass with biosurfactant addition $\left(\mathrm{L}_{1} \mathrm{~S}\right.$ is A-LD synthesized from lignin of black liquor of $A$. mangium isolated by 1 step method with ratio of lignin and PEDGE 1:3, reacted at $60^{\circ} \mathrm{C}$ for $1 \mathrm{~h} ; \mathrm{L}_{2} \mathrm{~S}$ is $\mathrm{A}-\mathrm{LD}$ synthesized from lignin of black liquor of $A$. mangium isolated by 2 step method with ratio of lignin and PEDGE 0.6:2, reacted at $60^{\circ} \mathrm{C}$ for $1 \mathrm{~h}$; LS is A-LD synthesized from commercial lignin with ratio of lignin and PEDGE $0.6: 2$, reacted at $60^{\circ} \mathrm{C}$ for 2 h. MA : maleic acid, OA: oxalic acid).

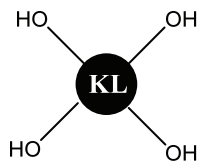

Kraft Lignin
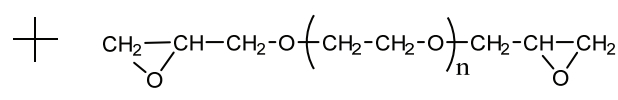

PEDGE

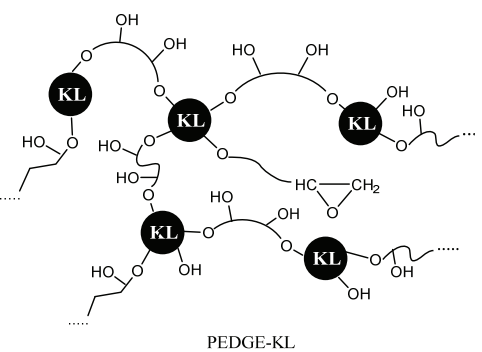

Fig. 1. Proposed reaction of PEDGE and A.mangium kraft lignin (KL) on A-LD synthesis (Fatriasari et al., 2020). 
biomass, respectively. As can be seen in Fig. 2, A-LD $\left(\mathrm{L}_{1} \mathrm{~S}, \mathrm{~L}_{2} \mathrm{~S}\right.$ and $\left.\mathrm{LS}\right)$ did not always give positive effect on sugar concentration.

In OPEFB and ST, the addition of A-LD cannot improve the sugar concentration of pre-treated OPEFB and ST. It is affected by the relative high lignin content in pre-treated OPEFB and ST that can inhibit the enzyme to access the cellulose. In the enzymatic hydrolysis system, lignin adsorbs the cellulase via hydrophobic interactions, electrostatic and hydrogen bonding interaction (Pareek et al., 2013; Nakagame et al., 2011). However, previous study reported that lignin isolation methods affect the lignin properties ( $\mathrm{Li}$ et al., 2016). Consequently, the biosurfactant synthesized was also affected, so that this A-LD did not give different performance in sugar concentration. Based on FTIR analysis of A-LD in Fatriasari et al. (2020), A-LD $\mathrm{L}_{2} \mathrm{~S}$ and A-LD LS have similar functional groups while $\mathrm{L}_{1} \mathrm{~S}$ has different functional groups with the A-LD $\mathrm{L}_{2} \mathrm{~S}$ and $\mathrm{LS}$, as well as shows the lowest surface tension. Lignin presence in pre-treated biomass decreased the maximum adsorption capacity of cellulases on cellulose, which was related with the reduction of available surface area of cellulose for cellulases due to adsorption of lignin on cellulose (Li et al., 2016). In addition, Li et al. (2018) reported that lignin is more easily absorbed the enzyme compared to cellulose, so that the enzymatic hydrolysis cannot perform well to result high sugar yield (Cheng et al., 2016).

Compared to pre-treated OPEFB and ST with higher lignin content, A-LD can work well in kraft pulp of SSB contained low lignin content. It means that lignin contributes significantly in inhibiting the enzyme work on the substrate. The mechanism of A-LD from kraft lignin as cellulase-aid agent to protect cellulase work effectively is shown in Fig. 3. These supported results were also reported in previous research (Winarni et al., 2013; Fatriasari et al., 2018; Fatriasari

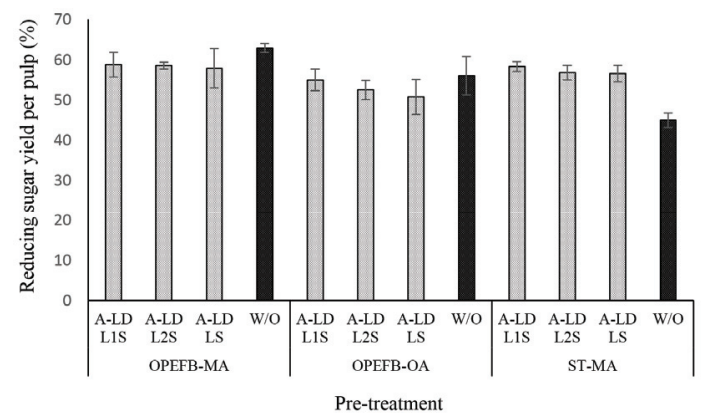

Fig. 4. Reducing sugar yield per pulp with biosurfactant addition $\left(\mathrm{L}_{1} \mathrm{~S}\right.$ is $\mathrm{A}-\mathrm{LD}$ synthesized from lignin of black liquor of $A$. mangium isolated by 1 step method with ratio of lignin and PEDGE $1: 3$, reacted at $60^{\circ} \mathrm{C}$ for $1 \mathrm{~h} ; \mathrm{L}_{2} \mathrm{~S}$ is A-LD synthesized from lignin of black liquor of $A$. mangium isolated by 2 step method with ratio of lignin and PEDGE $0.6: 2$, reacted at $60^{\circ} \mathrm{C}$ for $1 \mathrm{~h}$; LS is A-LD synthesized from commercial lignin with ration of lignin and PEDGE 0.6:2, reacted at $60^{\circ} \mathrm{C}$ for $2 \mathrm{~h}$. MA: maleic acid, OA: oxalic acid).
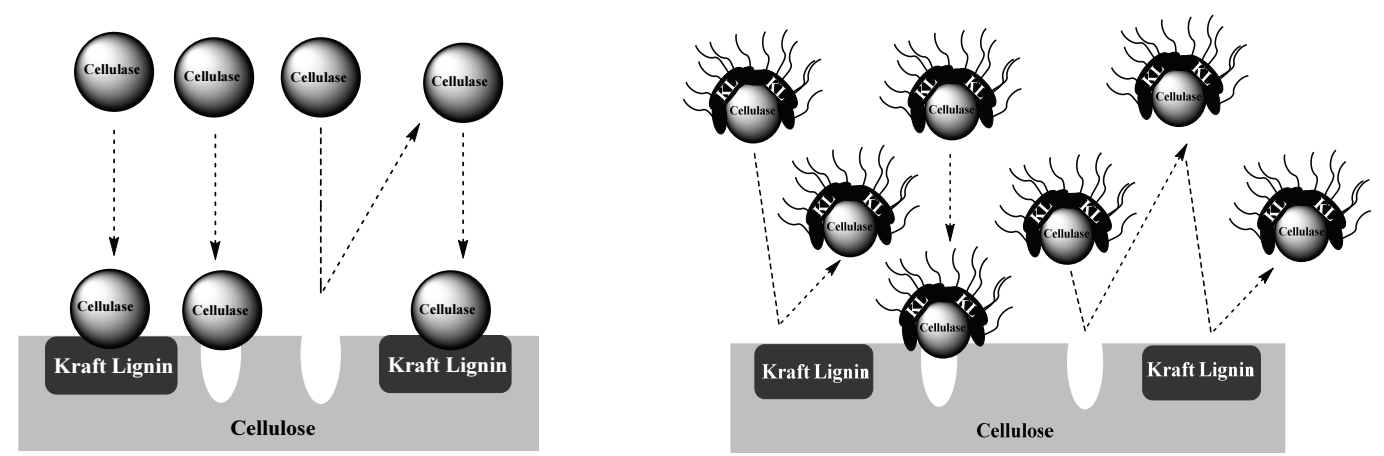

Fig. 3. Mechanism of A-LD as cellulase-aid agent (a) without, and (B) with the addition crude A-LD. 
Widya FATRIASARI - Fajar NURHAMZAH - Rika RANIYA $\cdot$ R.Permana Budi LAKSANA •

Sita Heris ANITA - Apri Heri ISWANTO - Euis HERMIATI

et al., 2020; Cheng et al., 2016).

Fig. 4 presents the performance of reducing sugar yield per pulp of pretreated biomass. Based on these results, the similar tendency is presented on the reducing sugar yield per pulp after A-LD addition. This means that A-LD does not give significant improvement on reducing sugar yield per pulp except on ST pre-treated maleic acid. Removing lignin after pretreatment contributes on reducing sugar yield per pulp results. Previous study of Fatriasari et al. (2020) reported that addition of A-LD on kraft pulp of SSB successfully improved the reducing sugar yield. In this study, pretreated biomass that was used as substrates contained high lignin compared to kraft pulp of SSB.

The presence of lignin in pretreated biomass has affected in the enzyme work on substrate as can be seen in Fig. 4 and 5. The difference of A-LD types did not always give the same effects on reducing sugar yield per pulp and per biomass. It means that the effectiveness of A-LD is influenced not only by the chemical composition of biomass but also by the other factors such as crystallinity of biomass, the degree of

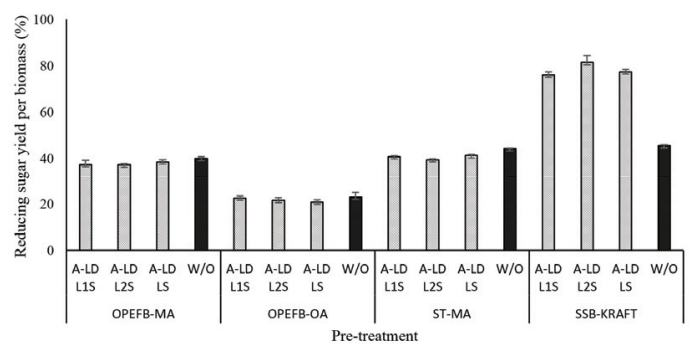

Fig. 5. Reducing sugar yield (RSY) per biomass with biosurfactant addition $\left(\mathrm{L}_{1} \mathrm{~S}\right.$ is A-LD synthesized from lignin of black liquor of $A$. mangium isolated by 1 step method with ratio of lignin and PEDGE 1:3, reacted at $60^{\circ} \mathrm{C}$ for $1 \mathrm{~h} ; \mathrm{L}_{2} \mathrm{~S}$ is $\mathrm{A}-\mathrm{LD}$ synthesized from lignin of black liquor of $A$. mangium isolated by 2 step method with ratio of lignin and PEDGE 0.6:2, reacted at $60^{\circ} \mathrm{C}$ for $1 \mathrm{~h}$; LS is A-LD synthesized from commercial lignin with ration of lignin and PEDGE $0.6: 2$, reacted at $60^{\circ} \mathrm{C}$ for $2 \mathrm{~h}$. MA : maleic acid, OA: oxalic acid). disruption of pretreated biomass, the possibility re-deposited lignin on the surface of pretreated biomass after pretreatment that needs to be further investigated. SSB kraft pulp has the highest degree of crystallinity, which was caused by high removal of amorphous fractions (lignin and hemicellulose) after kraft pulping and provide high cellulose (Table 3). Even though ST pre-treated maleic acid and OPEFB pre-treated oxalic acid have lower crystallinity compared to the others, but it does not always improve on the reducing yield per biomass.

The different trend on reducing sugar yield per biomass after addition of A-LD indicated that the possibility of specific interaction between types of biosurfactant and the substates. A-LD was not able to inhibit the lignin binding on the substrate with active site of enzyme during enzymatic hydrolysis. The addition of A-LD in the enzymatic hydrolysis of kraft pulp of SSB leads to improve reducing sugars productivity, compared to control. In kraft pulp of SSB, the competitive adsorption between cellulase and A-LD might be won by A-LD. There is significant difference on the reducing sugar yield per biomass with high and low lignin content in pre-treated biomass. Lignin can be absorbed by cellulase that could be released by reaching new adsorption equilibrium between lignin and supernatants. On the other hand, desorption of cellulases from lignin occurred by hydrolytic capacity. The maximum absorption capacity of cellulases on cellulose presence of lignin decreased (Li et al., 2016). These results supported that lignin content contributed in improving reducing sugar yield besides the bio-

Table 3. Degree of crystallinity of pre-treated biomass

\begin{tabular}{cc}
\hline Pre-treatment method & Crystallinity index (\%) \\
\hline \hline OPEFB pre-treated maleic acid & 44.97 \\
OPEFB pre-treated oxalic acid* & 40.61 \\
ST pre-treated maleic acid & 34.21 \\
SSB pre-treated kraft pulping & 54.80
\end{tabular}

* Anita et al. (2020) 
surfactant effect. The reducing sugar yield per biomass of SSB kraft pulp is higher than that of jabon alkali pulp (42\%) at the optimum condition of enzymatic hydrolysis using Tween 80 as surfactant (Nababan et al., 2020).

\section{CONCLUSION}

The evaluation of the effect of lignin content in pre-treated biomass on enzymatic hydrolysis performance of biomass has been performed. Lignin content in biomass has influence on the A-LD performance during enzymatic hydrolysis. The possibility of inhibition of lignin binding in substrate with A-LD addition could not be observed; therefore, there was no improvement of reducing sugar yield from substrates with high lignin content. A-LD can work effectively in improving enzymatic hydrolysis performance in biomass with low lignin content. This study confirmed that lignin has dominant effect in the effectiveness of cellulase activity during enzymatic hydrolysis. The types of A-LD did not give significant effects on reducing sugar yield improvement.

\section{REFERENCES}

Abdeli, F., Rigane, G., Salem, B., El Arbi., Aifa, S., Cherif, S. 2019. Use of surfactants and biosurfactants in oil recovery processing and cellulose hydrolysis. Journal of Bacteriology and Mycology 6(5): 1-4. Alinejad, M., Henry, C., Nikafshar, S., Gondaliya, A., Bagheri, S., Chen, N., Singh, S.K., Hodge, D.B., Nejad, M. 2019. Lignin-based polyurethanes: Opportunities for bio-based foams, elastomers, coatings and adhesives. Polymers 11(7): 1-21.

Anita, S.H., Fitria., Solihat, N.N., Sari, F.P., Risanto, L., Fatriasari, W., Hermiati, E. 2020. Optimization of microwave-assisted oxalic acid pretreatment of oil palm empty fruit bunch for production of fermentable sugars. Waste and Biomass Valorization 11(6): 2673-2687.

Arnieyanto, D.R. 2018. Praperlakuan pemanasan gelombang mikto dan asam untuk peningkatan hidrolisis selulosa daun tebu (Saccharum officinarum) oleh selulase. Tesis Program Studi Kimia, Fakultas Matematika dan Ilmu Pengetahuan Alam, Universitas Pakuan (In Indonesia).

Berlin, A., Balakshin, M., Gilkes, N., Kadla, J., Maximenko, V., Kubo, S., Saddler, J. 2006. Inhibition of cellulase, xylanase and beta-glucosidase activities by softwood lignin preparations. Journal of Biotechnology 125(2): 198-209.

Bin, Y., Chen, H. 2010. Effect of the ash on enzymatic hydrolysis of steam-exploded rice straw. Bioresource Technology 101(3): 9114-9119.

Cheng, N., Yamamoto, Y., Koda, K., Tamai, Y., Uraki, Y. 2014. Amphipathic lignin derivatives to accelerate simultaneous saccharification and fermentation of unbleached softwood pulp for bioethanol production. Bioresource Technology 173: 104-109.

Cheng, N., Koda, K., Tamai, Y., Yamamoto, Y., Takasuka, T.E., Uraki, Y. 2017. Optimization of simultaneous saccharification and fermentation conditions with amphipathic lignin derivatives for concentrated bioethanol production. Bioresource Technology 232: 126-132.

Choudhary, R., Umagiliyage, A.L., Liang, Y., Siddaramu, T., Haddock, J., Markevicius, G. 2012. Microwave pretreatment for enzymatic saccharification of sweet sorghum bagasse. Biomass Bioenergy 39: 218-226.

Daorattanachai, P., Viriya-empikul, N., Laosiripoiana, N., Faungnawakij, K. 2013. Effects of Kraft lignin on hydrolysis/dehydration of sugars, cellulosic and lignocellulosic biomass under hot compressed water. Bioresource Technology 144: 504-512.

Elgharbawy, A.A., Alam, M.Z., Moniruzzaman, M., Goto, M. 2016. Ionic liquid pretreatment as emerging approaches for enhanced enzymatic 
Widya FATRIASARI - Fajar NURHAMZAH - Rika RANIYA $\cdot$ R.Permana Budi LAKSANA •

Sita Heris ANITA - Apri Heri ISWANTO - Euis HERMIATI

hydrolysis of lignocellulosic biomass. Biochemical

Engineering Journal 109: 252-267.

Eriksson, T., Borjesson, J., Tjerneld, F. 2002. Mechanism of surfactant effect in enzymatic hydrolysis of lignocellulose. Enzyme and Microbial Technology 31(3): 353-364.

Fajriutami, T., Fatriasari, W., Hermiati, E. 2016. Effects of Alkaline pretreatment of sugarcane bagasse on pulp characterization and reducing sugar production. Jurnal Riset Industri 10(3): 147-161 (In Indonesia).

Fatriasari, W., Supriyanto, Iswanto, A.H. 2015. The kraft pulp and paper properties of sweet sorghum bagasse (Sorghum bicolor L Moench). Journal of Engineering and Technological Sciences 47(2): 149-159.

Fatriasari, W., Raniya, R., Anita, S.H., Hermiati, E. 2016. Conversion of oil palm empty fruit bunches (OPEFB) for bioethanol produce through microwave assisted organic acid pretreatment. Biorefinery Project Report (unpublished work).

Fatriasari, W., Anita, S. H., Risanto, L. 2017. Microwave assisted acid pretreatment of oil palm empty fruit bunches (EFB) to enhance its fermentable sugar production. Waste and Biomass Valorization 8: 79-91.

Fatriasari, W., Adi, D.T.N., Laksana, R.P.B., Fajriutami, T., Raniya, R., Ghozali, M., Hermiati, E. 2018. The effect of amphipilic lignin derivatives addition on enzymatic hydrolysis performance of kraft pulp from sorghum bagasse. IOP Conf. Series: Earth and Environmental Science 141(012005): 1-7.

Fatriasari, W., Hamzah, F.N., Pratomo, B.I., Fajriutami, T., Ermawar, R.A., Falah, F., Laksana, R.P.B., Ghozali, M., Iswanto, A.H., Hermiati, E., Winarni, I. 2020. Optimizing the synthesis of lignin derivatives from acacia mangium to improve the enzymatic hydrolysis of kraft pulp sorghum bagasse. International Journal of Renewable Energy Development 9(2): 227-235.

Fengel, D., Wegener, G. 1989. Chemistry, Ultrastructure,
Reaction, Walter de Gruyter, Berlin.

Focher, B., Palma, M.T., Canetti, M., Torri, G., Cosentino, C., Gastaldi, G. 2001. Structural differences between non-wood plant celluloses: Evidence from solid state NMR, vibrational spectroscopy and X-ray diffractometry. Industrial Crops and Products 13(3): 193-208.

Fortunati, E., Luzi, F., Puglia, D., Torre, L. 2016. Chapter 1 - Extraction of Lignocellulosic Materials from Waste Products Multifunctional Polymeric Nanocomposites Based on Cellulosic Reinforcements, pp. 1-38.

Goh, C.S., Tan, H.T., Lee, K.T. 2012. Pretreatment of oil palm frond using hot compressed water: An evaluation of compositional changes and pulp digestibility using severity factors. Bioresource Technology 110: 662-669.

Gómez, E.O., de Souza, R.T.G., de Moraes, R.G.J., de Almeida, E., Cortez, L.A.B. 2014. Sugarcane trash as feedstock for second generation processes. In: Cortez LAB (ed) Sugarcane bioethanol-R\&D for Productivity and Sustainability, Editora Edgard Blücher, São Paulo, pp. 637-660.

Goshadrou, A., Karimi, K., Taherzadeh, M.J. 2011. Bioethanol production from sweet sorghum bagasse by Mucor hiemalis. Industrial Crops and Products 34(1): 1219-1225.

Han, S-Y., Park, C-W., Kwon, G-J., Kim, J-H.,Kim, N-H., Lee, S-H. 2020. Effect of [EMIM]Ac recycling on Salix gracilistyla Miq. pretreatment for enzymatic saccharification. Journal of the Korean Wood Science and Technology 48(3): 405-413.

Helle, S.S., Duff, S.J.B, Cooper, D.G. 1993. Effect of surfactants on cellulose hydrolysis. Biotechnology and Bioengineering 42(5): 611-617.

Hendriks, A.T.W.M., Zeeman, G. 2009. Pretreatments to enhance the digestibility of lignocellulosic biomass. Bioresource Technology 100(1): 10-18. Hermiati, E., Oktaviani, M., Ermawar, R.A., Laksana, 
RPB, Kholida, LN, Thantowi, A., Mardiana, S.M., Watanabe, T. 2020. Optimization of xylose production from sugarcane trash by microwave- maleic acid hydrolysis. Reaktor 20(2): 81-88.

Iswanto, A.H., Aritonang, W., Azhar, I, Supriyanto, Fatriasari, W. 2017. The physical, mechanical and durability properties of sorghum bagasse particleboard by layering surface treatment. Journal of the Indian Academy of Wood Science 14: 1-8.

Jonsson, L.J., Alriksson, B., Nilvebrant, N.O. 2013. Bioconversion of lignocellulose: Inhibitors and detoxification. Biotechnology for Biofuels 6(16): $2-10$.

Jutakanoke, R., Tolieng, V., Tanasupawat, S., Akaracharanya, A. 2017. Ethanol production from sugarcane leaves by Kluyveromyces marxianus $\mathrm{S} 1.17$, a genome-shuffling mediated transformant. BioResources. 12(1): 1636-1646.

Kaar, W.E., Holtzapple, M.T. 1998. Benefits from tween during enzymic hydrolysis of corn stover. Biotechnology and Bioengineering 59(4): 419-427.

Kim, M.H., Lee, S.B., Ryu, D.D.Y., Reese, E.T. 1982. Surface deactivation of cellulase and its prevention. Enzyme and Microbial Technology 4(2): 99-103.

Kumar, D.S., Marimuthu, P. 2012. Sweet sorghum stalks-an alternate agro based raw material for paper making. IPPTA Journal 24(3): 47-50.

Lai, C., Tu, M., Shi, Z., Zheng, K., Olmos, L.G., Yu. 2014. Contrasting effects of hardwood and softwood organosolv lignins on enzymatic hydrolysis of lignocellulose. Bioresource Technology 163: 320-327.

Lee, J-W., Rodrigues, R.C.L.B., Kim, H.J., Choi, I-G., Jeffries, T.W. 2010. The roles of xylan and lignin in oxalic acid pretreated corncob during separate enzymatic hydrolysis and ethanol fermentation. Bioresource Technology 101(12): 4379-4385.

Li, Y., Sun, Z., Ge, X., Zhang, J. 2016. Effects of lignin and surfactant on adsorption and hydrolysis of cellulases on cellulose. Biotechnology for Bio- fuels 9(20): 1-9.

Li, X., Li, M., Pu, Y., Ragauskas, A.J., Klett, A.S., Thies, M., Zheng, Y. 2018. Inhibitory effects of lignin on enzymatic hydrolysis: The role of lignin chemistry and molecular weight. Renewable Energy 123: 664-674

Loow, Y.-L., Wu, T.Y., Md. Jahim, J., Mohammad, A.W., Teoh, W.H. 2016. Typical conversion of lignocellulosic biomass into reducing sugars using dilute acid hydrolysis and alkaline pretreatment. Cellulose 23(3): 1491-1520.

Lukmandaru, G. 2016. Correlation between extractive content and colour properties in teak heartwood. Jurnal Penelitian Hasil Hutan 34(3): 207-216.

Malmsten, M., Van Alstine, J.M. 1996. Adsorption of poly (ethylene glycol) amphiphiles to form coatings which inhibit protein adsorption. Journal of Colloid and Interface Science 177(2): 502-512.

Merklein, K., Fong, S.S., Deng, Y. 2016. Chapter 11. Biomass utilization in biotechnology for biofuel production and optimization. Biotechnology for Biofuel Production and Optimization, pp. 291-324.

Miller, G.L. 1959. Use of Dinitrosalicylic Acid Reagent for Determination of Reducing Sugar Analitical Chemistry 31(3): 426-428.

Min, C.H., Um, B.H. 2017. Effect of process parameters and kraft lignin additive on the mechanical properties of miscanthus pellets. Journal of the Korean Wood Science and Technology 45(6): 703-719.

Monrroy, M., Garcia, J.R., Mendonca, R.T., Baeza, J., Freer, J., Chil, J. 2012. Kraft pulping of Eucalyptus globulus as a pretreatment for bioethanol production by simultaneous saccharification and fermentation. Journal of the Chilean Chemical Society 57(2): 1113-1117.

Moodley, P., Kana, E.B.G. 2015. Optimization of xylose and glucose production from sugarcane leaves (Saccharum officinarum) using hybrid pretreatment techniques and assessment for hydrogen generation 
Widya FATRIASARI - Fajar NURHAMZAH - Rika RANIYA $\cdot$ R.Permana Budi LAKSANA •

Sita Heris ANITA - Apri Heri ISWANTO - Euis HERMIATI

at semi-pilot scale. International Journal of Hydrogen Energy 40(10): 3859-3867.

Mussatto, S.I., Fernandes, M., George, J.M.R., José, J.M.O., José, A.T., Roberto, I.C. 2010. Production, characterization and application of activated carbon from brewer's spent grain lignin. Bioresource Technology 101(7): 2450-2457.

Nababan, M.Y.S., Fatriasari, W., Wistara, N.J. 2020. Response surface methodology for enzymatic hydrolysis optimization of jabon alkaline pulp with Tween 80 surfactant addition. Biomass Conversion and Biorefinery.

https://doi.org/10.1007/s13399-020-00807-w

Nakagame, S., Chandra, R.P., Kadla, J.F., Saddler, J.N. 2011. The isolation, characterization and effect of lignin isolated from steam pretreated douglas-fir on the enzymatic hydrolysis of cellulose. Bioresource Technology 102(6): 4507-4517.

Oktaviani, M., Hermiati, E, Thontowi, A., Laksana, R.P.B., Kholida, L.N., Adriani, A, Yopi, W., Mangunwardoyo, W. 2019. Production of xylose, glucose, and other products from tropical lignocellulose biomass by using maleic acid pretreatment. IOP Conference Series: Earth Environmental. Science 251(012013): 1-9.

Pareek, N., Gillgren, T., Jönsson, L.J. 2013. Adsorption of proteins involved in hydrolysis of lignocellulose on lignins and hemicelluloses. Bioresource Technology 148: 70-77.

Patil, J.V., Chari, A., Rao, SV., Mathur, R.M., Vimelesh, B., Lal, P.S. 2011. High Bio-Mass Sorghum (Sorghum bicolor): An alternate raw material for pulp and paper making in India. IPPTA Journal 23(2): 161-165.

Punyamurthy, R., Sampath, K.D, Bennehalli, B., Srinivasa, C.V. 2013. Influence of esterification on the water absorption property of single abaca fiber. Chemical Science Transaction 2(2): 413-422.

Qing, Q., Yang, B., Wyman, C.E. 2010. Impact of surfactants on pretreatment of corn stover. Bioresource Technology 101(15): 5941-5951.

Rahikainen, J.L., Martin-Sampedro, R., Heikkinen, H., Rovio, S., Marjamaa, K., Tamminen, T., Rojas, O.J., Kruus, K. 2013. Inhibitory effect of lignin during cellulose bioconversion: The effect of lignin chemistry on non-productive enzyme adsorption. Bioresource Technology 113: 270-278.

Rowell, R.M., Pettersen, R., Han, J.S., Rowell, J.S., Tshabalala, M.A. 2005. Chapter 3: Cell Wall Chemistry in Handbook Wood Chemistry and Wood Composites, 1st ed., CRC Press, pp. 71-72.

Sills, D.L., Gossett, J.M. 2011. Assessment of commercial hemicellulases for saccharification of alkaline pretreated perennial biomass. Bioresource Technology 102(2): 1389-1398.

Singh, D.P., Trivedi, R.K. 2013. Acid and alkaline pretreatment of lignocellulosic biomass to produce ethanol as biofuel. International Journal of ChemTech Research. 5(2): 727-734.

Sjostrom, E. 1998. Wood Chemistry. Fundamentals and Applications. Gadjah Mada University Press. Yogyakarta.

Sjostrom, E. 1981. Wood Chemistry: Fundamentals and Applications, 2nd ed., Academic Press, San Diego, USA.

Sluiter, A., Hames, B., Ruiz, R., Scarlata, C., Sluiter, J., Templeton, D., Crocker, D. 2012. Determination of Structural Carbohydrates and Lignin in Biomass Technical Report NREL/TP-510-42618.

Solihat, N.N., Fajriutami, T., Adi, D.T.N., Fatriasari, W., Hermiati, E. 2017. Reducing sugar production of sweet sorghum bagasse kraft pulp. AIP Conference Proceeding. 1803: 020012-1 - 020012-8.

Uraki, Y., Ishikawa, N., Nishida, M., Sano, Y. 2001. Preparation of amphiphilic lignin derivative as a cellulase stabilizer. Journal of Wood Science 47(4): 301-307.

Wang, W., Zhuang, X., Yuan, Z., Yu, Q., Qi, W., 
Wang, Q., Tan, X. 2012. High consistency enzymatic saccharification of sweet sorghum bagasse pretreated with liquid hot water. Bioresource Technology 108: 252-257.

Wang, W., Wang, C., Zahoor, Chen, X., Yu, Q., Wang, Z., Zhuang, X., Yuan, Z. 2020. Effect of a nonionic surfactant on enzymatic hydrolysis of lignocellulose based on lignocellulosic features and enzyme adsorption. ACS Omega 5(26): 15812-15820.

Winarni, I., Koda K., Waluyo, T.K., Pari, G., Uraki, Y. 2014. Enzymatic saccharification of soda pulp from sago starch waste using sago lignin-based amphipathic derivatives Journal of Wood Chemistry and Technology 34(3): 157-168.

Winarni, I., Oikawa, C., Yamada, T., Igarashi, K., Koda, K.,Uraki, Y. 2013. Improvement of enzymatic saccharification of unbleached cedar pulp with amphipathic lignin derivatives. Bioresources 8(2): 2195-2208.

Wise, L.E., Murphy, M., Addieco, A.A. 1946. Chlorite holocellulose, Its fractionation and bearing on summative wood analysis and on studies on the hemicellulose. Paper Trade Journal 122(2): 35-43. Wright, R.T., Wiyono, E. 2013. USDA Foreign Agricultural Service: Indonesia oilseeds and products update. (http://gain.fas.usda.gov/Recent GAIN Pub lications/ Oilseeds and Products Update_Jakarta_ Indonesia_5-4-20), Accessed 27 Apr. 2017.

Xu, J., Cheng, J.J., Sharma-Shivappa, R.R., Burns, J.C. 2010. Sodium hydroxide pretreatment of switchgrass for ethanol production. Energy Fuels 24(3): 2113-2119.

Yanti, H., Syafii, W., Wistara, N.J., Febrianto, F., Kim, N.H. 2019. Effect of biological and liquid hot water pretreatments on ethanol yield from Mengkuang (Pandanus artocarpus Griff). Journal of the Korean Wood Science and Technology 47(2): 145-162.

Zong, Z., Ma, L., Yu, L., Zhang, D., Yang, Z., Chen, S. 2015. Characterization of the interactions between polyethylene glycol and cellulase during the hydrolysis of lignocellulose. BioEnergy Research 8(1): $270-278$. 